\title{
The Piney Branch site (District of Columbia, U.S.A.) and the significance of the quarry-refuse model for the interpretation of lithics sites
}

\author{
Curtis Runnels \\ Archaeology Program and Department of Anthropology, Boston University, 675 Commonwealth Avenue. \\ Boston MA 02215. U.S.A. Email: runnels@bu.edu
}

\begin{abstract}
:
In the 1870s the amateur archaeologist Dr Charles Abbott discovered roughly-flaked bifacial artefacts that he called "paleoliths" near Trenton, New Jersey, which he claimed were artefact types similar to Lower Palaeolithic handaxes being found in western Europe at that time. This interpretation gave rise to what has been called the Great Palaeolithic War, a debate in the United States about the existence of an "American Palaeolithic" that only ended in 1890 when the archaeologist William H. Holmes from the Smithsonian Institution excavated the Piney Branch lithics site in Washington D.C.. On the basis of the bifacial reduction sequence that he reconstructed from the lithics excavated at Piney Branch, Holmes argued that any resemblance of paleoliths to Lower Palaeolithic handaxes was accidental. Holmes believed that paleoliths were discarded elements from the sequential reduction of stone nodules (which he called the "Progressive Series") by recent American Indian knappers during the manufacture of projectile points. In other words, the Trenton paleoliths, and by implication similar roughly-flaked bifaces, were nothing more than quarry refuse (or "waste"). Since Holmes' day the quarry-refuse model for the interpretation of large roughly-flaked bifacial implements as "waste" and not artefact types used in other activities, particularly for lithics sties in the arid western regions of the US, has been applied at times without adequate bridging arguments. A review of Holmes' interpretation of the Piney Branch evidence suggests that his quarry-refuse model, even when applied to Piney Branch, required numerous untested assumptions, and that the model may inadvertently obscure a range of other prehistoric activities not strictly related to quarrying and knapping. As a consequence, the application of the quarry-refuse model today to lithics sites found in North America without careful examination may also fail to identify the complete range of cultural activity at those sites, and should be applied to lithics sites only with due caution and the testing of alternative hypotheses.
\end{abstract}

Keywords: paleoliths; Progressive Series; quarry-refuse model; roughly-flaked bifacial artefacts; lithics sites

Published by the School of History, Classics and Archaeology, University of Edinburgh ISSN: 2055-0472. URL: http://journals.ed.ac.uk/lithicstudies/

Except where otherwise noted, this work is licensed under a CC BY 4.0 licence. 


\section{Introduction}

Dr Charles C. Abbott discovered large $(>10 \mathrm{~cm})$ lithic artefacts, often roughly flaked bifacially, in what were thought to be Pleistocene terrace gravels in the Delaware River Valley near Trenton, New Jersey, in the 1870s (Figure 1) (Abbott 1876; 1878; 1881). Dubbed "paleoliths," the large artefacts have invasive hard-hammer flaking covering both faces with two relatively straight edges converging to a distal point. Abbott believed that paleoliths were identical to Lower Palaeolithic handaxes in Europe and were evidence of an "American Palaeolithic" (e.g., Evans 1872: fig. 414; Shea 2013: 55-60). Abbott also claimed that the paleoliths were stratified in what were then thought to be Pleistocene river terraces, contexts similar to those first investigated by Jacques Boucher de Perthes in the Somme River Valley in northwestern France. Abbott's discoveries convinced some scholars that paleoliths were indeed Palaeolithic (Meltzer 2015: 172), and the American Palaeolithic had a wide currency in archaeological circles for several decades (Adovasio \& Page 2003: 90-100; Meltzer 2009: 68-79; Meltzer \& Dunnell 1992: xiv-xviii).
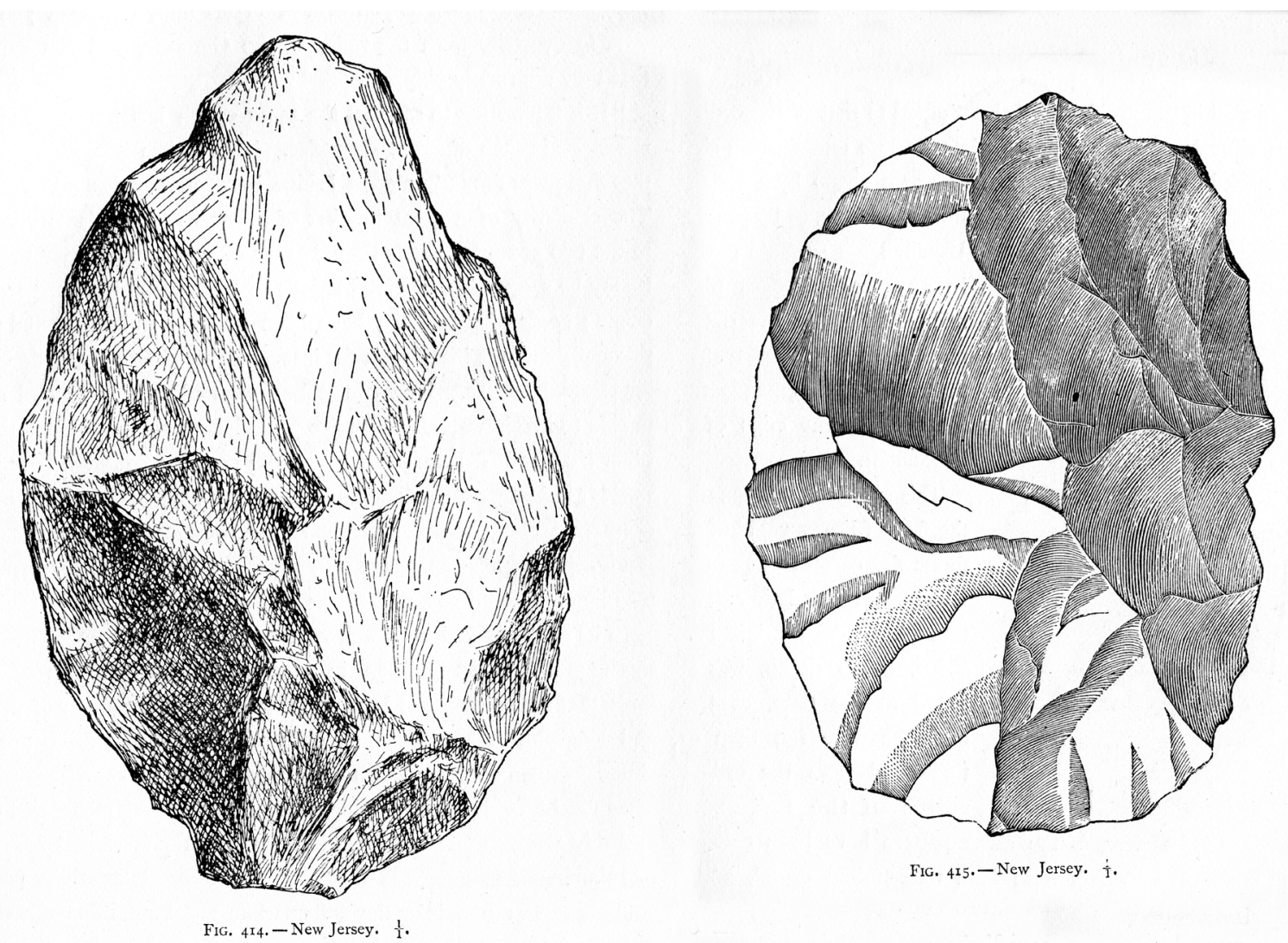

Figure 1. Paleoliths from Trenton, New Jersey. Artefact on the left is ca. $12 \mathrm{~cm}$ in length. Source Abbott 1881: figs. 414 and 415 .

Unfortunately for Abbott, who was sometimes referred to as the Boucher de Perthes of the New World, the American Palaeolithic had a short life. The debate about the paleoliths and the American Palaeolithic has been called the Great Palaeolithic War, a bitter controversy about the presence of humans in the Pleistocene New World (Meltzer 2015). Proponents and opponents disagreed about the geologic context of the paleoliths, the methods of excavation, and the resemblance of the paleoliths to Old World artefact-types (morphotypes). Though the American Palaeolithic was accepted at first by both professional and amateur archaeologists and geologists, opposition to it arose, at least in part, from the desire of professional 
archaeologists in the Bureau of American Ethnology (BAE) in Washington, D. C., to draw the interpretation of American prehistory into their hands (Meltzer 2015: 439-444).

A chief protagonist in the Great Palaeolithic War was William Henry Holmes of the BAE, who is credited with demonstrating that the archaeological methods of amateurs like Abbott left the contexts of the paleoliths in doubt and that the resemblance of paleoliths to European handaxes was accidental (Holmes 1890; 1892; 1893a-b; Meltzer 2015: 129-138). Holmes highlighted the lack of systematic investigation by Abbott and the probability that few if any of the paleoliths had been found in secure geologic contexts. His strongest argument, however, was based on his excavations at the Piney Branch site at Washington D.C. only a few miles from his office in the BAE (Holmes 1890). On the basis of his excavations, Holmes argued that paleoliths from Piney Branch which resembled European Palaeolithic handaxes had been created fortuitously by recent American Indians through the process of bifacial reduction of large pieces of lithic raw material to make projectile points. Holmes concluded that the Piney Branch knappers reduced large quartzite cobbles in order to produce smaller thinner unifacial and bifacial preforms, which were in turn reduced bifacially through successive stages down to thin "leaf-blades" that were subsequently removed from the site before being used as preforms for the manufacture of small bifacial projectile points (Holmes 1890). This explanation carried the day, and the Trenton paleoliths and the American Palaeolithic were all but forgotten (Meltzer 2015: 430-432). The question of the presence of Pleistocene humans in North America was only taken up again decades later, only after the recognition of the Folsom culture in New Mexico in the 1920s (Meltzer 2015: 456-468). Holmes' quarry-refuse model, however, did more than lay to rest the paleolith controversy; it has continued to influence thinking about lithics sites to this day, sometimes uncritically.

Holmes interpreted Piney Branch as a lithic quarry where all cultural materials were part of a single reduction sequence, and all of the lithics were forms of quarry refuse. For the quarry-refuse hypothesis to work, however, the interpretation requires many untested assumptions (Holmes 1890; 1892; 1893a-b). Although Holmes claimed that he selected the Piney Branch site for excavation to test the idea that paleoliths like those from Trenton were Palaeolithic, he believed that Piney Branch was an historical period Indian lithic quarry before he began work there (Meltzer 2015: 132-133) and it is probable that this a priori position influenced Holmes' assumptions and interpretations. Therefore, a reconsideration of the assumptions underlying the interpretation of Piney Branch (Holmes 1897) is desirable because the Piney Branch quarry-refuse explanation for paleoliths is used, and perhaps misused, today by some archaeologists to interpret large roughly-flaked bifacial artefacts as rejected early-stage reduction preforms (see below). Although the quarry-refuse model may work at times, it should be applied only with caution (even perhaps for Abbott's paleoliths in the Trenton Gravels; see Volk 1911).

\subsection{Piney Branch and the Progressive Series}

Holmes excavated colluvial and alluvial deposits incised by the Piney Branch, a tributary of Rock Creek in the District of Columbia (Figure 2). Holmes selected this site to prove that paleoliths were recent quarry refuse, and based largely on the results of his excavations Holmes concluded that the American Palaeolithic was a chimera created by amateurs who misinterpreted the geologic contexts of paleoliths and mistakenly compared quarry rejects with Palaeolithic handaxes on the basis of superficial morphological features (Adovasio \& Page 2003: 90-100; Meltzer 2009: 68-79; Meltzer 2015: 129-138; Meltzer \& Dunnell 1992: xiv-xviii; 120-139).

Holmes published the results of the Piney Branch excavations in well-illustrated publications and his conclusions resulted in the acceptance by most scholars of the quarry- 
refuse explanation for paleoliths (e.g., Holmes 1890; 1892; 1893a-b; 1897; Meltzer 2015: 129-138). What has been overlooked, however, is that the quarry-refuse model was only a hypothesis. Holmes excavated a relatively small area that he thought was representative of the site chronologically and culturally, and he interpreted the deep (4 meters) deposit as one short cultural event by one group of people in recent times (Figure 3). He assumed that the artefacts belonged to a single cultural component.

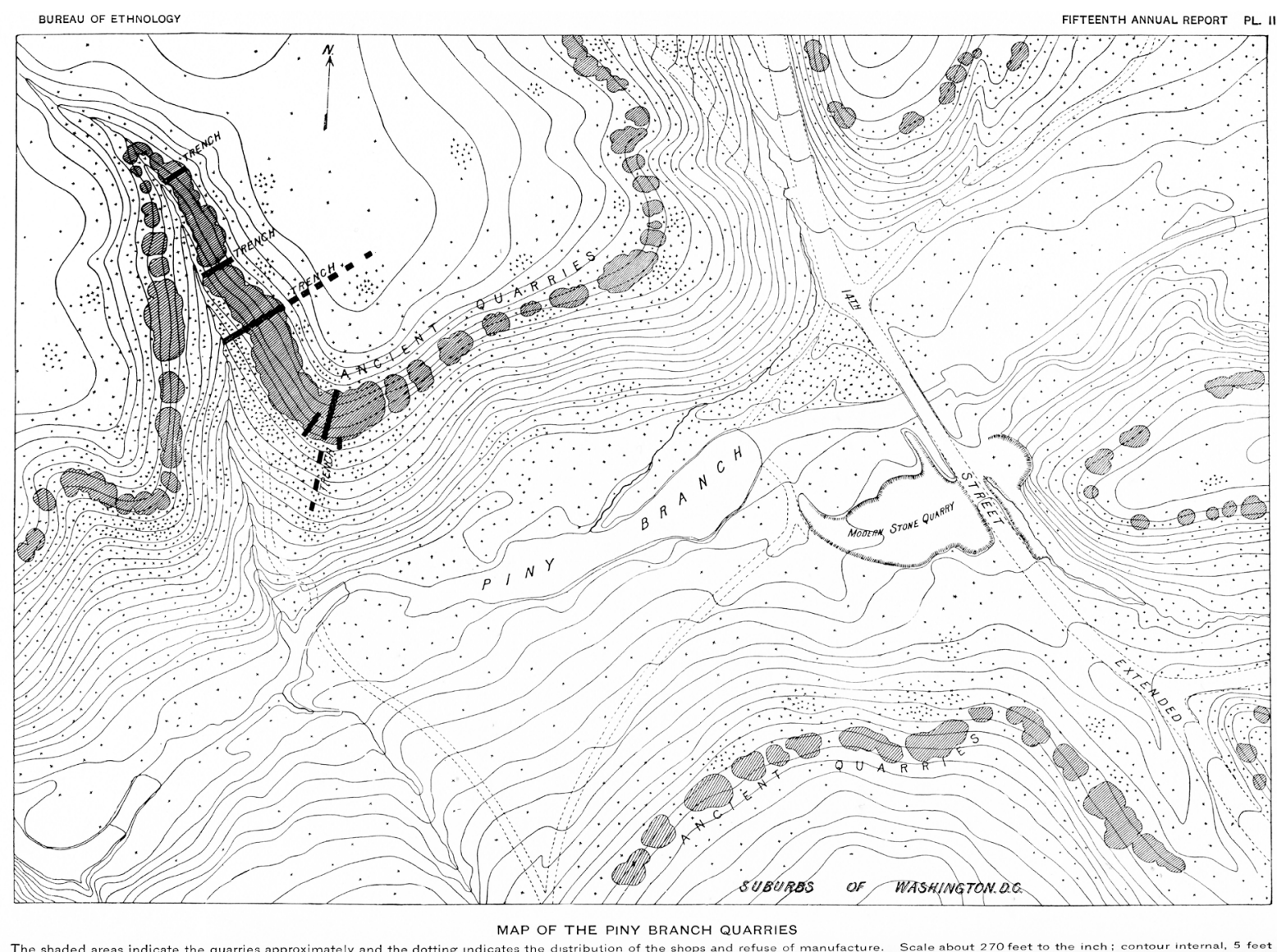

Figure 2. Map of the Piney Branch Site (District of Columbia) showing the locations of Holmes' excavation trenches as black bars. Scale approximately 82 meters (270 feet) to each 2.54 centimeters (one inch). After Holmes (1897: plate II). [Original caption: The shaded areas indicate the quarries approximately and the dotting indicates the distribution of the shops and refuse of manufacture. Scale about 270 feet to the inch; contour interval, 5 feet]

Based on these assumptions, Holmes argued that the artefact assemblage was part of a single lithic reduction sequence and that all of the artefacts were lithic preforms that had been rejected by the knappers during the reduction process: they were "not made to be used...[and] we have...confirmation of this in the fact that it is exceptional to find examples...that show evidence of use, or...were found in such situations as to indicate that they had either been used or valued" (Holmes 1890: 17). In other words, paleoliths were early-stage reduction forms resulting from the production of preforms for the manufacture of small projectile points such as those found on sites in the Chesapeake region inhabited by historically-known Indian groups. Paleoliths were reduced by bifacial flaking from cobbles to form thin bifacial "leafblade" preforms that were removed from the quarry (Figure 4). What is more, Holmes argued that the quarry had never been occupied by the Indians, but only visited briefly from time to time when new leaf-blades were needed to make projectile points. 


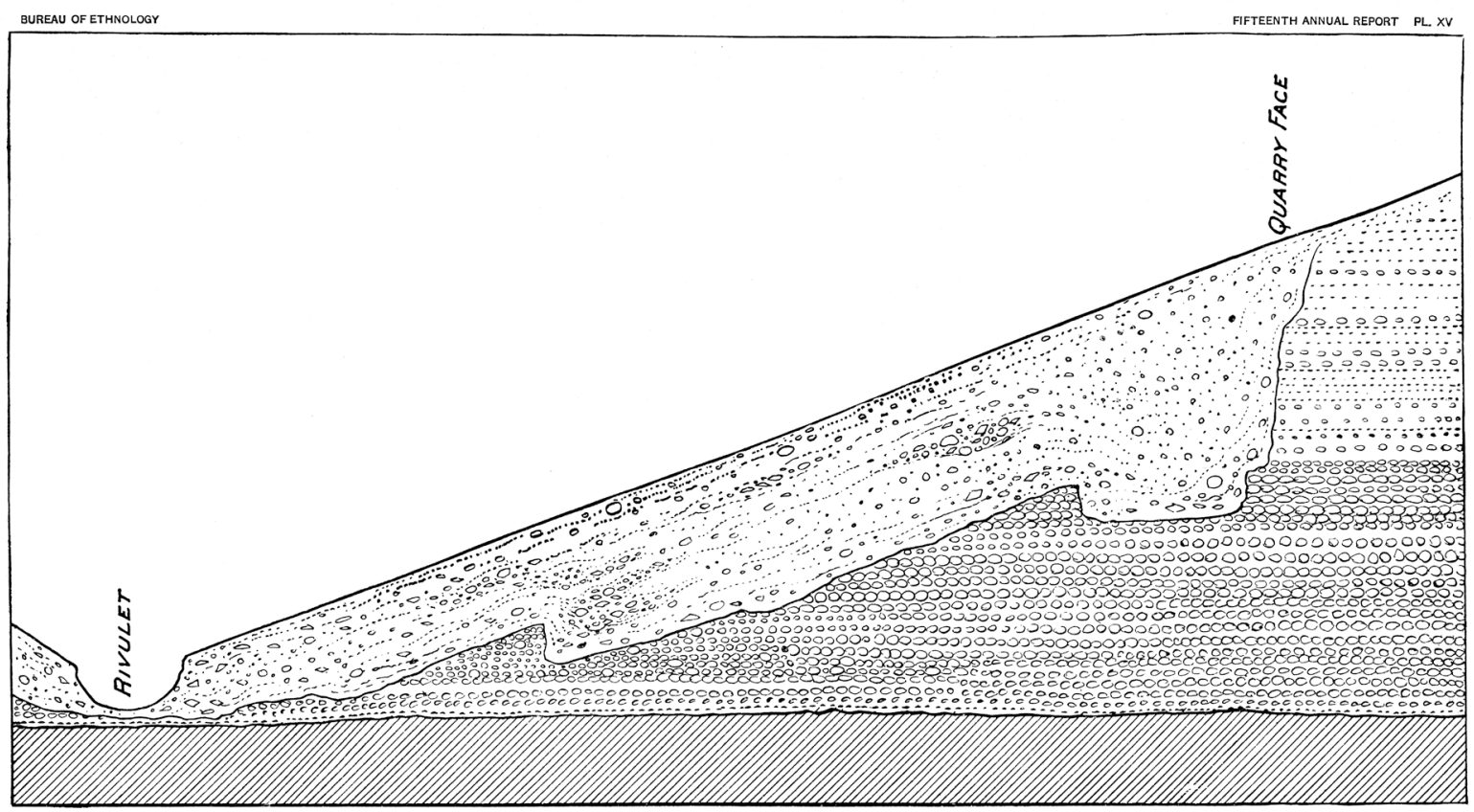

SECTION SHOWING DEPOSITS FILLING THE QUARRY EXPOSED BY THE THIRD TRENCH. QUARRY FACE 13 FEET IN HEIGHT

Figure 3. Colluvial deposits at Piney Branch. After Holmes 1897: plate XV. [Original caption: Section showing deposits filling the quarry exposed by the third trench. Quarry face 13 feet in height]
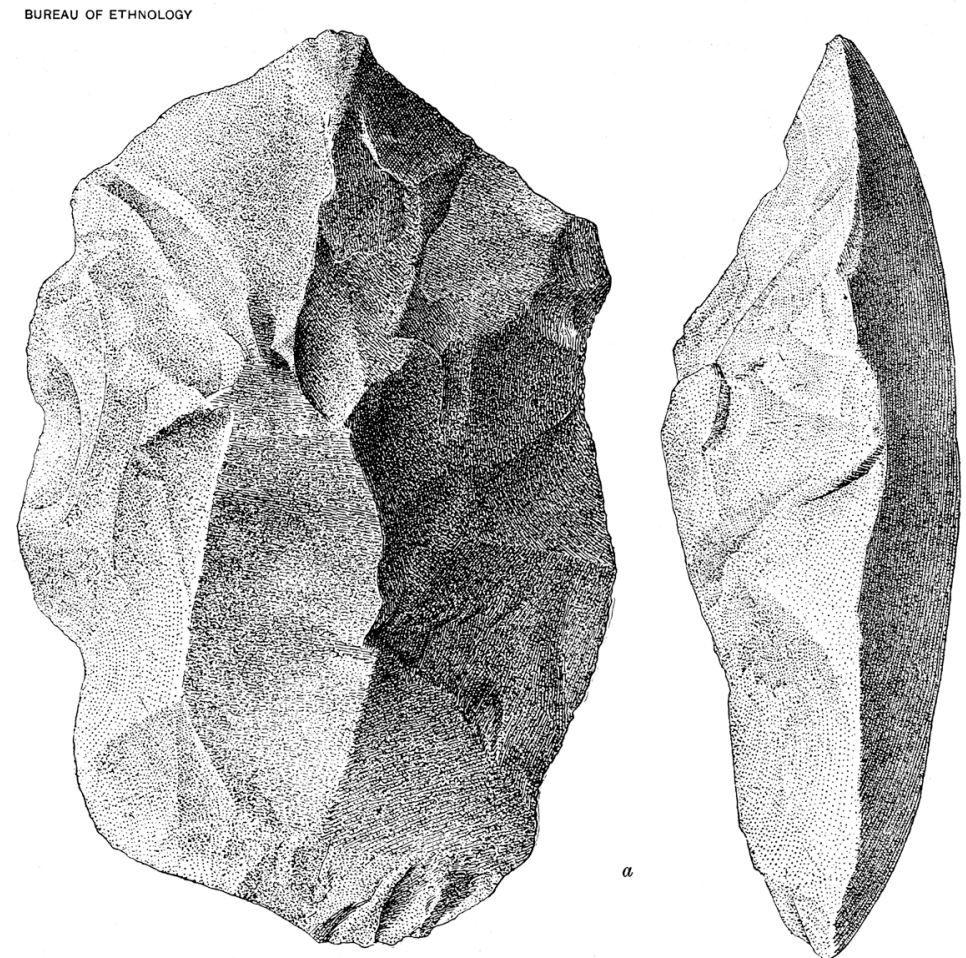

FIFTEENTH ANNUAL REPORT PL. XXIV

TWO SPECIMENS OF FLAKED STONE THAT, TOGETHER WITH THE LOWER SPECIMEN OF PLATE XXIII AND THE FLAKES MADE IN SHAPING THEM,
WERE FOUND IN A SINGLE CLUSTER (ACTUAL SIZE)

Figure 4. Paleolith and leaf-blade from Piney Branch. The piece on the left is 10-12 cm in length. After Holmes (1897: plate XXIV). [Original caption: Two specimens of flaked stone that, together with the lower specimen of Plate XXIII and the flakes made in shaping them, were found in a single cluster (actual size)]

The crucial assumption was that the only activity at Piney Branch was the extraction of raw material and early stage reduction by knapping. Holmes, however, excavated only a small part of the site even though lithic artefacts occur in gravel outcrops along the Piney Branch 
terraces over an area measuring more than 415 by 580 meters. Holmes' four excavation trenches were confined to the northwestern portion of the site, where the long $(14 \mathrm{~m})$ trenches ran upslope from the streambed to a vertical exposure of a natural stratum of quartzite cobbles that he referred to as the "quarry face," although it is unclear if he had any evidence that it was artificially cut, rather than eroded (Figure 5).

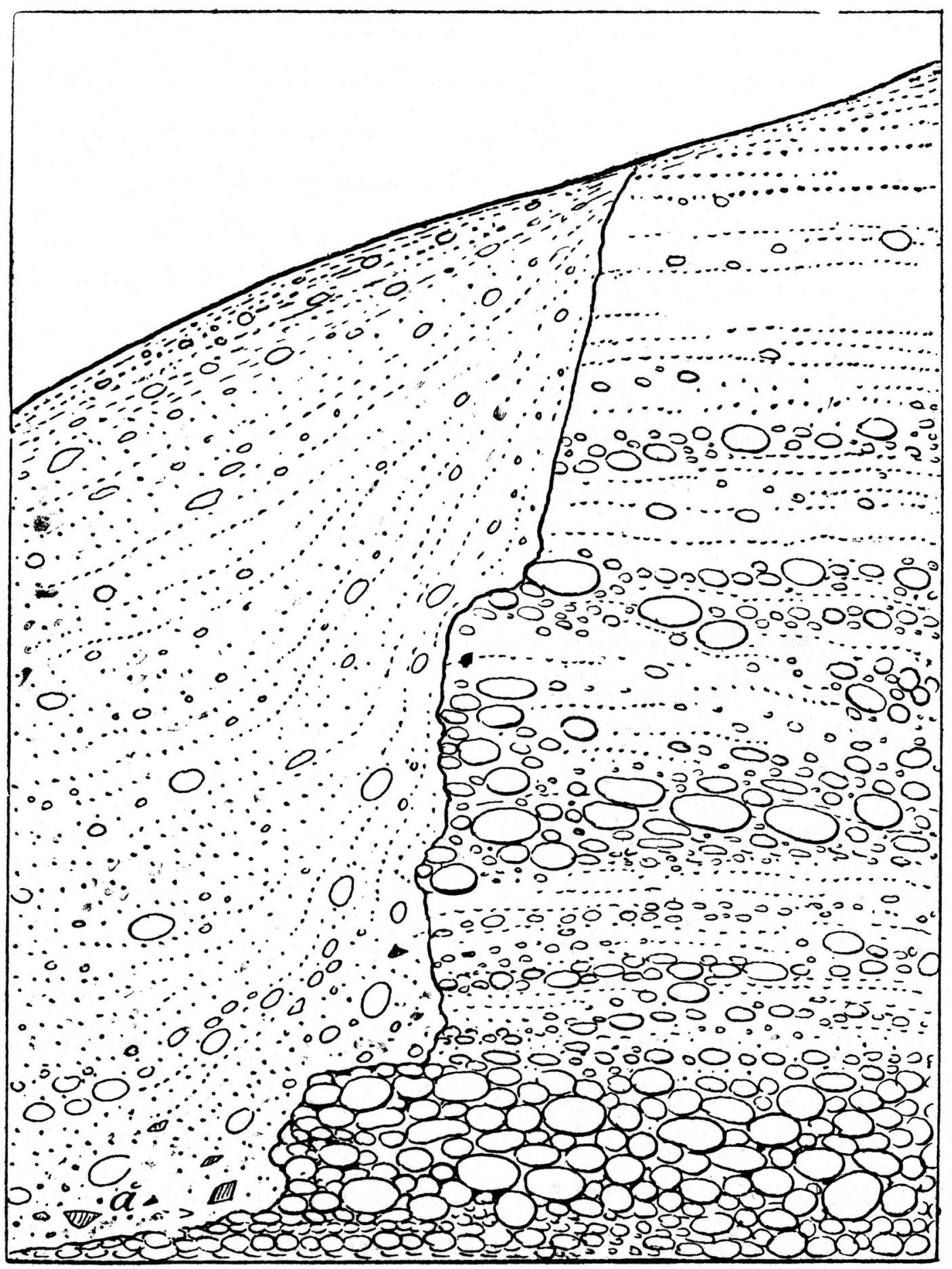

\section{Fig. 8-Section of bowlder beds exposed in quarry face 13 feet in height.}

Figure 5. Cut bank in the natural deposits of quartzite cobbles and boulders at Piney Branch interpreted as a “quarry face” by Holmes. After Holmes 1897: fig. 8. [Original caption: Section of bowlder beds exposed in quarry face 12 feet in height.' 
Holmes estimated the volume of the excavated deposits at ca. 1000 cubic feet, or about one one-thousandth of the volume of the total deposits at the site (Holmes 1890: 10; Holmes 1897: 21). He estimated the total number of artefacts at Piney Branch to be more than a million (Holmes 1890: 10). From the excavated sample, he selected 1000 artefacts for study, or about $0.10 \%$ of the total. Today we have no way of knowing if this sample is representative of the total site, and obviously it is possible that the unexcavated deposits at Piney Branch may preserve other cultural components or evidence for cultural activities other than quarrying. Unfortunately, there has been little research at the site since Holmes' time, and I limit the discussion to the published data to ask whether other hypotheses about the function(s) of the site are possible.

Holmes believed that there was no stratification at Piney Branch and that the deposits had formed recently and rapidly as "one period of work...by one race....and one ideal," and had only been worked for a matter of years or "a couple of centuries" by local Algonquian Indians (Holmes 1890: 20; Meltzer 2015: 132). Current archaeological opinion, however, is that activity began there as early as the Archaic (ca. 4000 years ago or more) and continued for an unknown period of time (Meltzer 2015: 472-473). The beginning and end limits for the use or occupation of the site remain unknown, nor do we know if any part of the site was used or occupied continuously or intermittently. But the assumption that Holmes' sample was the result of a single episode of deposition is not supported by the available data.

The further assumption that the entirety of the deposits at Piney Branch accumulated rapidly and very recently is questionable. For example, his published sections depict four strata above the "undisturbed gravel" (labeled "bedrock;" Holmes 1897: 31, 40, 47), and the contacts between the layers (Figures 6 and 7) may have resulted from erosional events that removed deposits, which would represent missing periods of time. These observations suggest that the deposits accumulated over a longer period than Holmes was willing to consider, and if the deposits accumulated intermittently, there is reason to doubt that the artefacts from the deposits from top to bottom were the result of a single cultural component.

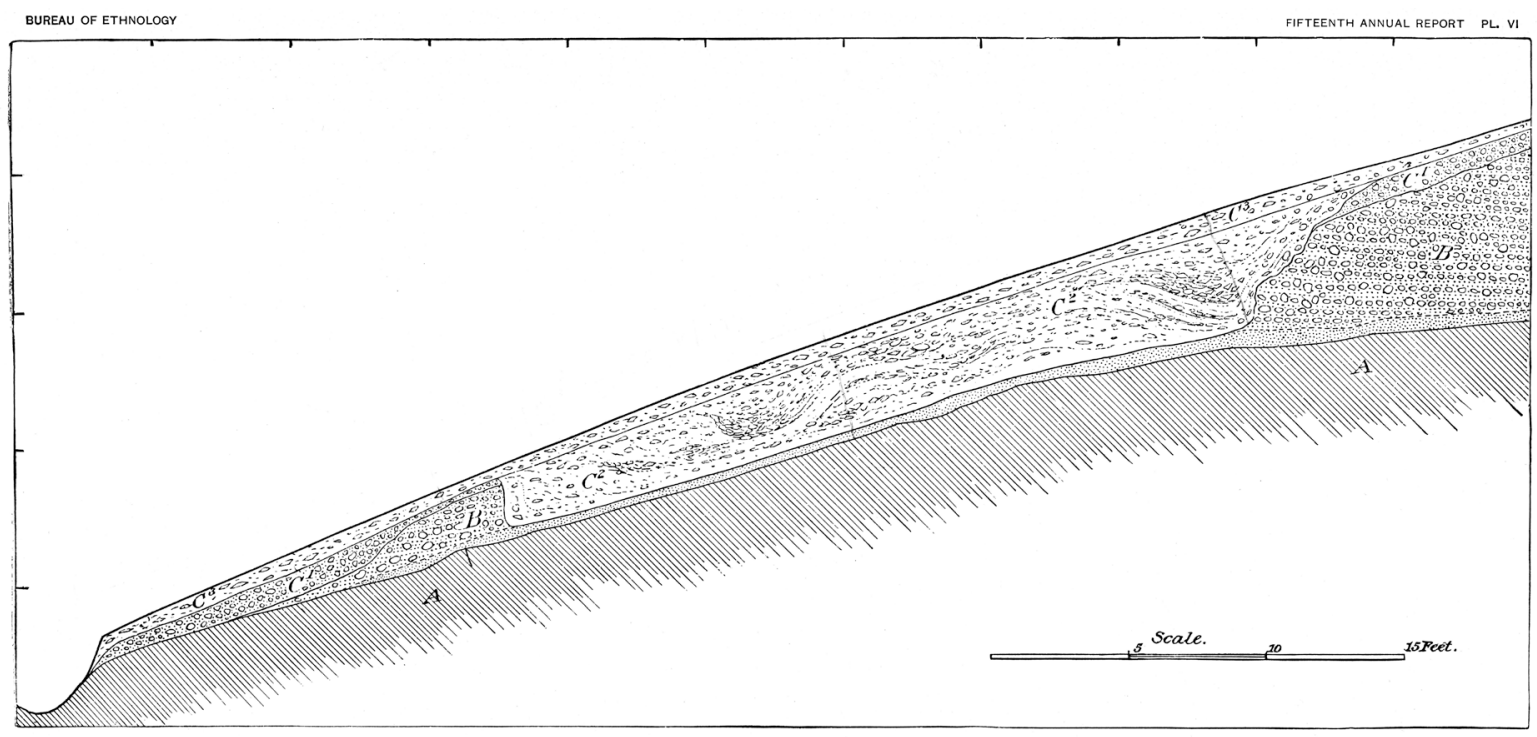

SECTION OF QUARRY EXPOSED BY THE FIRST TRENCH

$a$, Mica schists; $b$, Potomac (Mesozoic) bowlder beds; $c^{1}$, Preartificial slope gravels; $c^{2}$, Deposits of shop refuse, showing traces of pits; $c^{3}$, Materials rearranged by natural forces since the period of quarrying

Figure 6. Section of the deposits at Piney Branch showing colluvial strata that may have missing-time erosional surfaces. After Holmes 1897: plate VI. [Original caption: Section of quarry exposed by the first trench. A, Mica schists; b, Potomac (Mesozoic) bowlder beds; $c^{1}$, Preartificial slope gravels; $c^{2}$, Deposits of shop refuse, showing traces of pits; $\mathrm{c}^{3}$, materials rearranged by natural forces since the period of quarrying] 


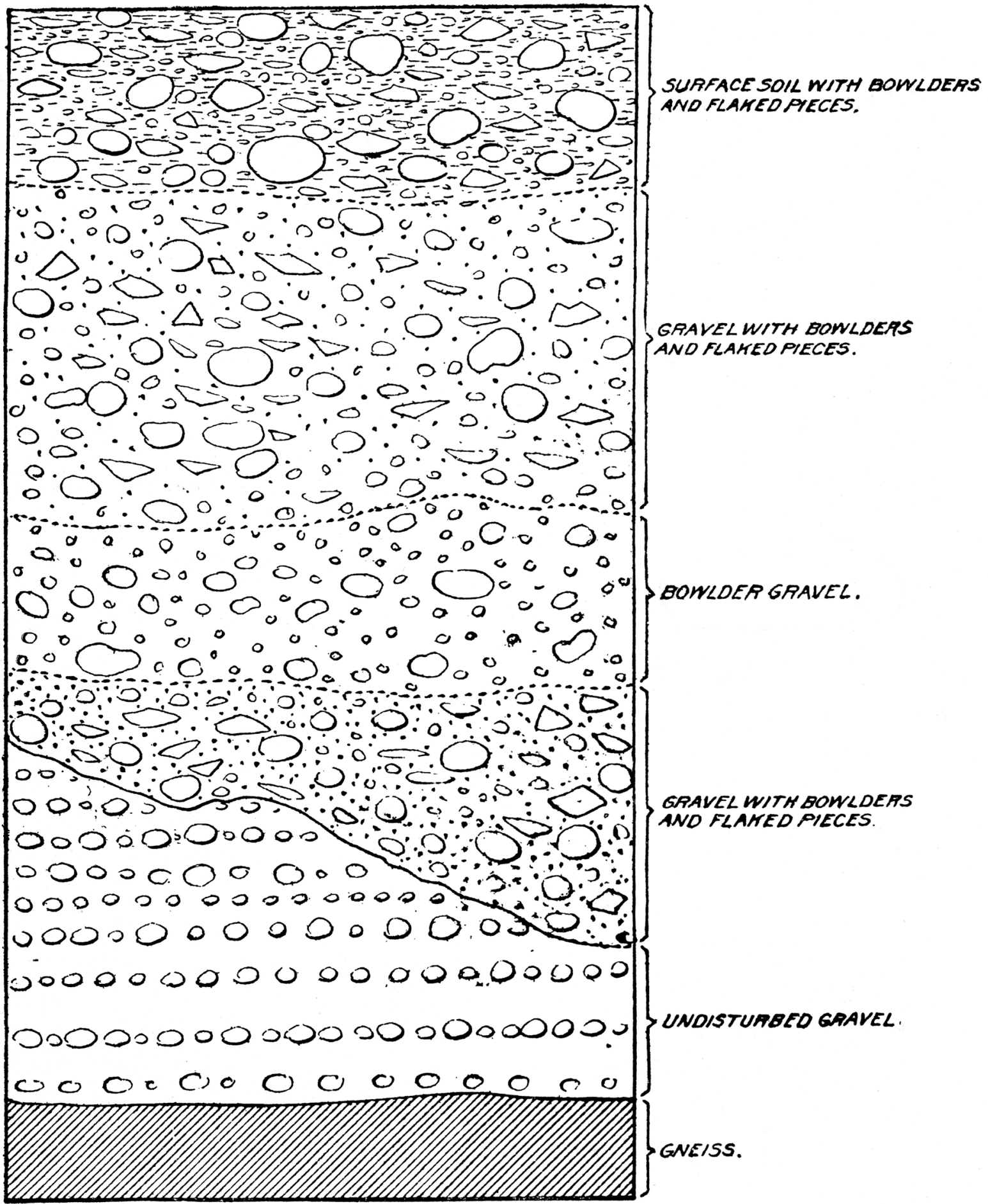

FIG. 7-Cross section at the fortieth foot.

Figure 7. Deposits at Piney Branch showing four strata overlying the undisturbed gravel at the base. After Holmes 1897: fig. 7. [Original caption: Cross section at the fortieth foot. (Strata are labelled, from bottom to top) Gneiss. Undisturbed gravel. Gravel with bowlders and flaked pieces. Bowlder gravel. Gravel with bowlders and flaked pieces. Surface soil with bowlders and flaked pieces.]

Holmes made other assumptions to rule out non-quarrying activities. Despite the small spatial extent of his test trenches, he argued that the evident lack of pottery, ground stone tools, and other non-lithic artefacts was not the effect of the limited area of excavation, but was the pattern for the whole site. He argued that the Indians had no "apparent reason" for bringing anything like pottery or ground stone tools to the site since it was only used for 
quarrying flaked lithic preforms (Holmes 1890: 21). Thus the lack of non-lithic artefacts was in an example of circular reasoning - both the evidence for the use of the site as a quarry workshop and explained by the use of the site as a quarry workshop.

Holmes had other arguments to support the hypothesis of a single period of use. Lithic implements throughout the deposits, for example, exhibited the same morphological forms, and "the chips struck from these objects were in the cluster with them, and there can be no doubt that all these forms, covering the whole range of so-called tools from the rudest [paleolith] to the final blade, were made by the same man and on the same day and probably within a single hour....Unity of time as well as of race are thus demonstrated" (Holmes 1890: 20). But this assumption is based on one "pocket of refuse" that contained one paleolith, two leaf-blades, and a few flakes (Figure 4) (Holmes 1890: 20). In his analysis Holmes did not include all categories of artefacts at the site, and by doing so he may have overlooked the existence of retouched artefact-types or in present day terminology technologically-defined tools (Debénath and Dibble 1994: 43-56), morphotypes that might point to other cultural activities at the site such as woodworking, butchery, or the maintenance of tools and weapons (Bryan 1950: 6-7).

His most significant contribution was his hypothesis of the "Progressive Series" model of stone tool reduction stages (Figure 8). The Progressive Series began with unworked cobbles that were reduced through as many as 13 successive stages in order to fashion smaller, thinner, bifacial leaf-blades. The leaf-blades were in turn removed from the site to be used as preforms for the manufacture of small bifacial projectile points (Figure 9). Based on the Progressive Series concept, Holmes argued that "paleoliths" were simply the crude roughouts made at the start of the reduction process, which were subsequently discarded by the knappers before they were completed. In the Progressive Series concept all such rough forms, therefore, were without exception quarry refuse, “mere waste,” or "trash” (Holmes 1890: 14).

As Meltzer notes, the Progressive Series was based on contemporary thinking about biological evolution that Holmes borrowed from the biologist Ernst Haeckel and his concept that ontogeny recapitulates phylogeny. Holmes applied this concept to stone tool manufacture and argued that paleoliths recapitulated early cultural stages of stone tool-making, much as an embryo recapitulated early stages of biological evolution, accounting for their resemblance to early Stone Age implements (Holmes 1890; Meltzer 2015: 130-132, 412). Meltzer links Holmes' Progressive Series to a stated goal of John Wesley Powell, the director of the BAE, to attribute all archaeological sites to historically known Indian tribes in order to refute the Moundbuilder myth, and to conform with prevailing uniformitarian thought about the continuity of population in the New World (Meltzer 2015: 128-129). The American Palaeolithic of Abbott and his followers, which posited a human presence in North America in the Pleistocene, would, if true, have meant that there were humans in the New World before the Indians, which was an unacceptable hypothesis for Powell, and, by extension, also for BAE employees (Meltzer 2015: 412-413, 424-425). Thus Holmes' proposal of the Progressive Series as an explanation for paleoliths rested upon a uniformitarian assumption of continuity among groups through time with no room for migration or replacement as much as it was based on the evidence from the Piney Branch excavations.

The Progressive Series has other problems. It does not account for all cultural activity observed at Piney Branch. Holmes illustrated the Progressive Series with successive rows of stone artefacts from Piney Branch running from left to right and from top to bottom. At the top are minimally-flaked cobbles and roughly-worked preforms (the so-called "paleoliths"), followed by progressively reduced preforms that continue down through multiple steps to the final leaf-blade preforms at the bottom right (Figure 8). But what was the evidence for this smooth sequence of reduction stages? The pieces used to illustrate the Progressive Series did not come from the same strata, and we do not know if they were even associated 
stratigraphically, much less functionally. Holmes constructed the Progressive Series by selecting 1000 shaped pieces out of "many tons" of stones from the excavated deposits without regard to depth, stratigraphy, or association of artefacts (Holmes 1890: 14). Holmes' selection of specimens was based on the "best exemplars" to illustrate the reduction stages (Holmes 1897: 54). The best exemplars were in turn identified through the undefined concept of "evidence of design" (Holmes 1890: 11). Today, we may well ask how any stone artefact at Piney Branch received any form without the knapper's “design.” It is probable that Holmes "cherry-picked" or "high graded" the specimens he needed to make up his Progressive Series, ignoring artefacts that didn't fit the model. And by constructing the Progressive Series to conform to the concept of biological evolution, he assumed - rather than demonstrated - that the artefacts belonged to one idealized reduction sequence wherein the roughly-worked preforms ("paleoliths") that resembled Palaeolithic handaxes retained an ancestral resemblance to early cultural forms, while more "advanced" leaf-blades were created through further reduction.
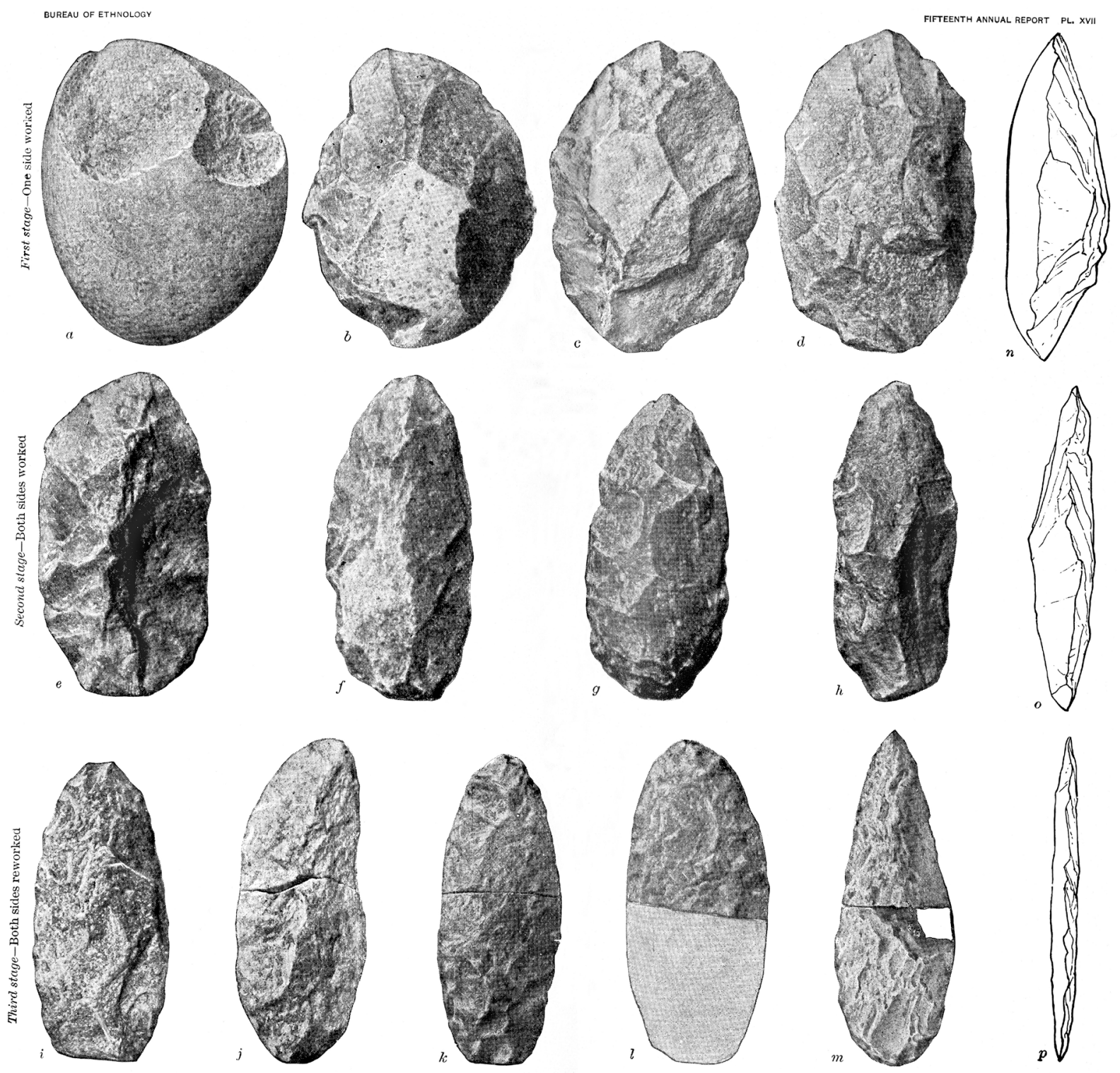

QUARRY-SHOP REJECTS-PROGRESSIVE SERIES, BEGINNING WITH THE BOWLDEF AND ENDING WITH THE THIN BLADE

Figure 8. Holmes' Progressive Series. The cobble at the top left is approximately $11.5 \mathrm{~cm}$ in length, and the piece at the lower right is a final-stage preform. After Holmes 1897: plate XVII. [Original caption: Quarry-shop rejects - Progressive Series beginning with the bowlder and ending with the thin blade] 
BUREAU OF ETHNOLOGY
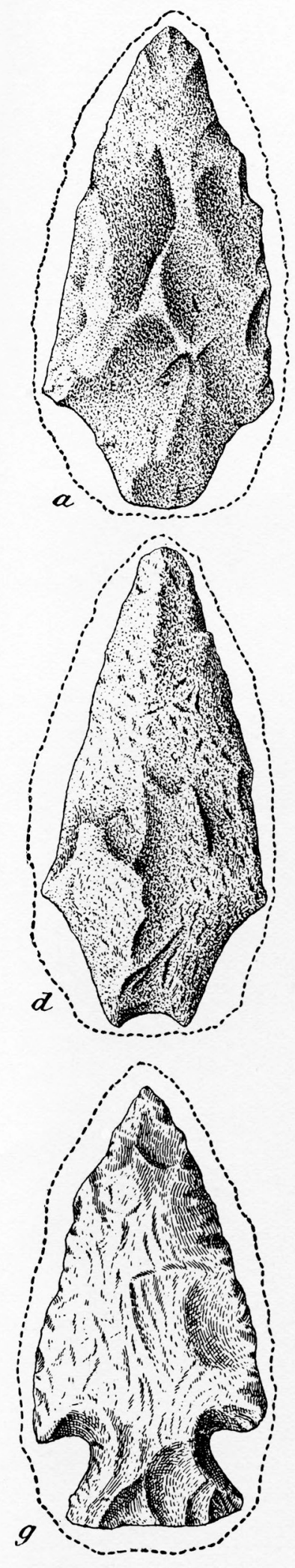

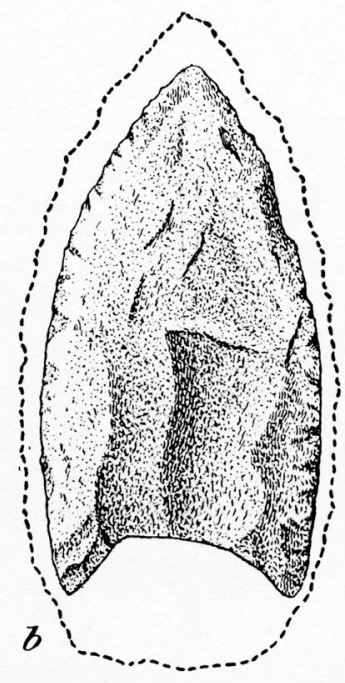

FIFTEENTH ANNUAL REPORT PL. XXXII
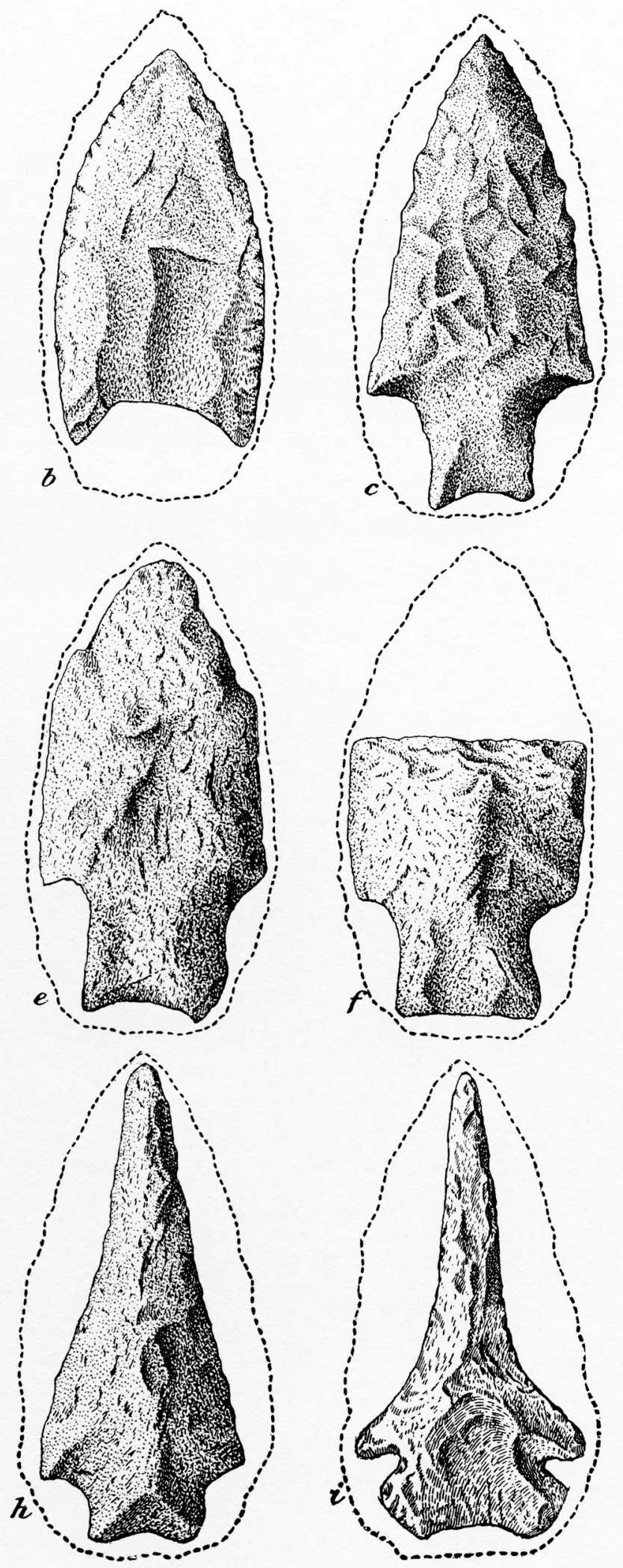

RELATION OF SPECIALIZED LEAF-BLADE IMPLEMENTS OF VARIOUS KINDS TO THE ORIGINAL BLADE

Figure 9. Bifacial projectile points knapped from Holmes' "leaf-blades.” Note the fluted point (b), evidence that Holmes mixed materials of different dates when constructing his Progressive Series. After Holmes 1897: plate xxxii. [Original caption: Relation of specialized leaf-blade implements of various kinds to the original blade] 
Based on his findings from Piney Branch, Holmes applied his quarry-refuse model and the Progressive Series concept to Abbott's paleoliths at Trenton.

"[T]he rudest forms [in Trenton], corresponding to our failure shapes [i.e., quarry refuse at Piney Branch], are obtained from glacial gravels....In the Potomac valley... all the rude forms appear to be but failures or unfinished pieces representing stages in the manufacture of arrow and spear points of the Indian...[and] it may be held that as in biology the growth of the individual epitomizes the successive stages through which the species passed, so in art the flaked-stone tool of the highest type advances through stages of manufacture each step of which illustrates a period of human progress in culture" (Holmes 1890: 23).

Not only were the Trenton paleoliths quarry refuse, but for Holmes paleoliths everywhere in North America were also "mere waste" in his words.

"[T]he evidence...furnished...by certain recently acquired knowledge of the contents of quarries and [work] shops where modern aboriginal flaked implements were made...[has] shown that all rudely flaked forms....are sufficiently accounted for without the necessity of assuming a very rude state of culture, and that any people...would in roughing out [leaf]blades - the principal product of the flaking process - produce precisely these forms and in great numbers as refuse" (Holmes 1893b: 15, emphasis added).

This concept has had lasting consequences, despite the questionable assumptions, and in my opinion the Progressive Series concept and quarry-refuse model should be regarded as hypotheses to be tested and be used only with caution as an explanation for any lithic assemblage.

\section{Discussion and Conclusions}

Holmes' interpretation of Piney Branch could be right, yet without new research at the site it is not possible from the publication alone to know the full range of functions or components at the site. The quarry-refuse model based on the publication has nevertheless been used for more than a century, in some cases without due regard for the unanswered questions about the interpretation of Piney Branch raised here. We may doubt, for example, that the Piney Branch deposits were the result of only one relatively short period of use, however reasonable an assumption it was for Holmes to make at the time, and research on prehistoric lithic quarries in recent times indicates that raw material sources are typically exploited over long and discontinuous periods of time resulting in the accumulation of large quantities of lithic materials. Thus Holmes' assumption that all artefacts from Piney Branch were byproducts of quarrying and knapping from one period is questionable. Wilmsen, for example, doubted "the validity of [Holmes'] reconstructed manufacturing sequence [from Piney Branch]," (Wilmsen 1965: 178), and Bryan identified problems with Holmes' interpretations, noting that he had not proved the short term duration of the work at Piney Branch nor accounted for the lack of finished products at the site. Bryan also questioned Holmes' assertion that paleoliths had never been used as tools, claiming that some of Holmes' "knapping errors," especially bilateral breaks, were evidence of heavy use (Bryan 1950: 7, 2225). Bryan did not believe that the goal of the Piney Branch knappers was confined to making projectile points, which, he noted are usually manufactured from small flakes or blades struck from large cores rather than by reducing large cores directly into small points. He found that "Holmes' theory of the derivation of the arrow head from a blade-like core ["leaf blades"] is erroneous...to make a thin blade, it is preferable...to begin with a thin slab" (Bryan 1950: 10, 22; see also Whittaker 1994: 152-161). Therefore the Progressive Series concept remains an 
untested hypothesis for Bryan: “[Holmes'] concept that a quarry existed solely for the production of exportable material...led to insufficient analysis of [other] evidence.” He notes that "similar bifaces have an uncertain position in our chronology, in part because they have not been given sufficient study [but] have been dismissed as 'blanks' or 'rejects'” (Bryan 1950: 4).

It is also likely that the quartzite outcrop at Piney Branch attracted knappers for millennia rather than centuries (Meltzer 2015: 472-473), and the extraction activities at Piney Branch are only one part of the history of the site. There were probably several separate behavioural episodes, as well as multiple cultural components, that resulted in a continuum of coarse timeaveraged formation processes, including the quotidian behaviour connected with periods of residence (e.g., Fotiadis 2016; Malinsky-Buller et al. 2011; Skarpelis et al. 2017). Separate cultural components would not be composed of refuse alone, at least not in the strict sense of "mere waste" as Holmes put it, but would consist of a mix of finished and unfinished implements, some of which were used at the site by the knappers, while others may have been left for future use, both for quarry working and for domestic needs. To take one North American example, at the Pleasantdale (New York) quarry or workshop about a third of the bifaces roughed out there were taken out of the production process and retouched or utilized into morphotypes for uses other than stone tool production (Brumbach 1987). And today it is widely believed that lithic quarries or workshops were resorted to over time for recycling and subsequent extraction and stone tool-making (Bailey \& Galanidou 2009). In other words, while Piney Branch was most likely at times used as a stone-tool quarry as Holmes thought, it may also be a cultural landscape with raw material outcrops, the remains of stone tool production, evidence of curation and discard, residential activities, and the infrastructure and features linked to these activities (Bloxam \& Heldal 2008: 20-22).

The effect of Holmes interpretation of the Piney Branch evidence on the reception of paleoliths and the American Palaeolithic, however, was overwhelming. Not only did most scholars accept Holmes' belief that paleoliths were a chimera created by amateurs, but the same could be said about the Acheulean handaxes in western Europe. Perhaps they too were quarry refuse? Otis Mason, for example, went so far as to speculate that in the future Jacques Boucher de Perthes, who had found the first recognized Palaeolithic handaxes in France, would perhaps be considered the "Dr. Abbott of France" (Meltzer 2015: 412). But that was taking things too far. Old World Palaeolithic handaxes are not quarry refuse; they are technologically-defined tools. As this was not fully realized in his time, it left Holmes free to apply his quarry-refuse and Progressive Series models in the widest possible manner. Noting "to a limited extent" the "rude forms" that he called waste were found "scattered over the Potomac valley outside of the [work]shops on the hills," which would "seem to conflict with my former statement that all of these rude shapes are failures and were left upon the factory sites" (Holmes 1890: 17), he escaped this contradiction by redefining his terms so that a lithic workshop become "any spot where an individual desiring to make an implement" has left even one large, roughly-worked lithic artefact (Holmes 1890: 17). In short, large roughlyworked bifacial artefacts made any findspot a workshop, quarry, or knapping site. Thanks to this reasoning, the quarry-refuse model could be used to argue that all lithic findspots with large roughly worked bifaces were knapping workshops, a conclusion that has been often applied to undated surface lithics sites, particularly in the Great Basin and other arid regions of North America (see below). We may well ask if the uncritical application of Holmes' conclusions from Piney Branch may have inadvertently led to sweeping technologicallydefined tools belonging to distinct cultural traditions from lithics sites into the category of quarry refuse without the benefit of bridging arguments or supporting evidence.

The Progressive Series model of the reduction of raw material to finished artefact-type has widely influenced lithic analysis in the New World (Shott 2003; 2017). The most 
important contribution to lithic studies to build upon this concept was proposed by Errett Callahan who introduced the idea of numbered reduction stages based on his extensive experimental knapping study of the manufacture of Clovis points in the eastern U.S. (Callahan 1979; 1991). His model simplifies Holmes' original Progressive Series (which was also based on experimental studies) comprising five stages in the production of finished projectile points created through the progressive reduction of preforms from pieces of raw material in order to fashion finished artefact-types: Stage 1, obtaining the blank; Stage 2, initial edging; Stage 3, primary thinning; Stage 4, secondary thinning; and Stage 5, shaped piece (Callahan 1979: 10-11, tables 1-2). Callahan's simple model of numbered reduction stages - including modifications and variations of them - is now widely applied to prehistoric lithic industries (Shott 2017: 2).

Holmes, and later Callahan, used quarry-refuse and reduction-stage models as hypotheses to be tested rather than final explanations for all lithic assemblages, but these models continue to be used uncritically as explanations. This is sometimes the case in the arid lands of the western United States where large accumulations of lithics on surface sites are common and are often interpreted as quarries or workshops. In southern California, large bifacial artefacts found on surface sites associated with Pleistocene paleolakes have been interpreted by separate research groups as early-stage quarry refuse, an assumption based explicitly on Holmes and Callahan. In the analysis of late Pleistocene to early Holocene lithics in the Soda Mountains area of California, for example, Knell and his colleagues observed that "foragers...created many early stage bifaces and flake blanks that (for the most part) were modified into projectile points away from the quarry" (Knell et al. 2014: 56). Knell also applied Callahan's stages to the lithics he studied from sites around pluvial Lake Mojave:

"Each non-projectile point bifacial tool and tool blank...was assigned to one of Callahan's (1979; 1991) stages of manufacture: Stage 1 (blank or obtaining the blank), Stage 2 (initial edging), Stage 3 (primary thinning), Stage 4 (secondary thinning; biface shaped or thinned to within the final set of flake removals), and Stage 5 (finished product)." (Knell 2014: 217).

The reduction stage concept has also been used to interpret the controversial Lake Manix industry that is characterized by large bifacial artefacts, which have sometimes been claimed as "Palaeolithic." In his analysis of the industry, however, Glennan concluded that the "crude large percussion flaked bifaces" in the assemblages were not finished implements like handaxes (i.e., artefact-types), but were "blanks, preforms and workshop rejects" (Glennan 1976: 43, 58). Likewise, Bamforth and Dorn concluded that large Lake Manix bifaces are not intentionally made functional tools but "early-stage quarry reduction debris" for the production of projectile points or other small tools (Bamforth \& Dorn 1988: 223).

But how can we be certain that large roughly worked bifacial artefacts like the ones from California are quarry refuse? In some cases that assumption may indeed be the best choice, especially if a source of raw material is near to the site. Yet the possibility of long timetransgressive cultural activity complicates the interpretation of such sites as quarries or workshops. Lithics sites in the Mojave Desert of California, are often associated with desert pavements, which were once thought to be deflationary, but are now explained by an inflationary model of soil formation that concentrates stone tools on a vesicular A horizon overlying fossil soil horizons on which the desert pavement floats as the soil horizons mature and thicken (McFadden 2013; 2017; McFadden et al. 1998). As a result, desert pavements may preserve palimpsests of stone tools from multiple cultural components. The difficulty is that different lithic forms may be grouped together to form a reduction sequence on the assumption that the artefacts are contemporary elements within a single cultural component, and the resulting sequence will mix artefacts from multiple episodes of activity. This is often the case with roughly-worked bifacial artefacts, which may be technologically-defined tools 
but are interpreted as rejected preforms. In other words, lining up stone tools on the laboratory table and sorting them into the hypothetical reduction sequence originally posited by the Progressive Series may seem intuitive - and validated by long historical practice - but it cannot be relied upon, at least when dealing with the lithic palimpsests, without due regard for evidence that would link larger, rougher pieces to smaller finished artefacts chronologically and culturally in a single functional reduction sequence. Such a priori assumptions should always be the null hypothesis to be tested along with other working hypotheses. As Shott puts it, [reduction] stages must be "demonstrated, not assumed" (Shott 2003: 101). The use of this intellectual shortcut, viz. that large roughly-flaked, bifacial artefacts are early-stage reduction preforms, may save time in reaching an interpretation of a site's function, but it hinders the evaluation of alternative hypotheses that might otherwise be used to untangle distinct prehistoric behaviours.

We must remain open to alternative explanations and be prepared to consider the possibility that large roughly-flaked bifacial artefacts may be technologically-defined tools with a wide array of functions ranging from quarry working to other activities connected with the residential needs, such as game butchering, hideworking, or the processing of plants. The Progressive Series and quarry-refuse models do not need to be discarded, as they may be the best explanations in many cases, but some sites, such as the lithic palimpsests in the western United States, may require alternative hypotheses, such as the possibility that large roughlyflaked bifacial artefacts are technologically-defined tools rather than production preforms or quarry waste.

\section{Acknowledgements}

I thank the College of Arts and Sciences at Boston University for financial support, Michael Hamilton of the Archaeology Program for his aid in preparing the figures, and the Editors of JLS and two anonymous reviewers for their efforts to improve this article. I also thank Priscilla Murray and Justin Holcomb for reading early drafts of the manuscript.

\section{References}

Abbott, C.C. 1876, The Stone Age in New Jersey, Annual Report of the Smithsonian Institution 1875. Government Printing Office, Washington D.C.: p. 246-380.

Abbott, C.C. 1878, Second report on the Paleolithic implements from the glacial drift, in the valley of the Delaware River, near Trenton, N. J. In: Annual Report of the Peabody Museum of American Archaeology and Ethnology. Salem Press, Salem Massachusetts: p. $225-257$.

Abbott, C.C. 1881, Primitive Industry: Or Illustrations of the Handiwork, in Stone, Bone and Clay, of the Native Races of the Northern Atlantic Seaboard of America. George A. Bates, Salem Massachusetts, 560 p. doi:10.1038/025027a0

Adovasio, J.M. \& Page, J. 2003, The First Americans: In Pursuit of Archaeology's Greatest Mystery. Modern Library, New York, 352 p.

Bailey, G. \& Galanidou, N. 2009, Caves, palimpsests and dwelling spaces: examples from the Upper Palaeolithic of south-east Europe. World Archaeology, 41: 215-241. doi:10.1080/00438240902843733.

Bamforth, D. \& Dorn, R. 1988. On the Nature and Antiquity of the Manix Lake Industry. Journal of California and Great Basin Anthropology, 10(2): 209-226.

URL: https://digitalcommons.unl.edu/anthropologyfacpub/24 
Bloxam, E. \& Heldal, T. 2008, Identifying heritage values and character-defining elements of ancient quarry landscapes in the Eastern Mediterranean: an integrated analysis. Work Package, 8. URL: http://www.quarryscapes.no

Brumbach, H. J.,1987, A quarry/workshop and processing station on the Hudson River in Pleasantdale, New York. Archaeology of Eastern North America, 15: 59-83. URL: https://www.jstor.org/stable/40914355

Bryan, K. 1950, Flint Quarries - The Sources of Tools and, At the Same Time, The Factories of the American Indian. Papers of the Peabody Museum of American Archaeology and Ethnology Volume XVII, Number 3. Peabody Museum, Cambridge Massachusetts, $40 \mathrm{p}$.

Callahan, E., 1979, The basics of biface knapping in the eastern fluted point tradition. A manual for flintknappers and lithic analysts. Archaeology of Eastern North America, 7(1): 1-180. URL: https://www.jstor.org/stable/40914177

Callahan, E. 1991, Out of theory and into reality: A comment on Nami's comment. Plains Anthropologist, 36(137): 367-368. doi:10.1080/2052546.1991.11909644

Debénath, A. \& Dibble, H.L. 1994, Handbook of Paleolithic Typology: Lower and Middle Paleolithic of Europe. University of Pennsylvania Museum, Philadelphia, 202 p. doi:10.9783/9781934536803

Evans, J. 1872, The Ancient Stone Implements, Weapons, and Ornaments, of Great Britain. Longmans, Green, Reader, \& Dyer, London, 640 p. doi:10.1017/CBO9781316155455

Fotiadis, M. 2016, Leaf-points from Petrota (Greek Thrace) and the Palaeolithic chronology of the Vrahos chert quarry. Annual of the British School at Athens, 111: 1-11. doi:10.1017/s0068245416000046

Glennan, W. 1976, The Manix Lake industry: Early lithic tradition or workshop refuse? Journal of New World Archaeology, 1: 43-62.

Holmes, W.H. 1890, A quarry workshop of the flaked-stone implement makers in the District of Columbia. American Anthropologist, 3: 1-26. doi:10.1525/aa.1890.3.1.02a00020

Holmes, W.H. 1892, Modern quarry refuse and the Palaeolithic theory. Science, 20: 295-297. doi:10.1126/science.ns-20.512.295

Holmes, W.H. 1893a, Gravel man and Palaeolithic culture; a preliminary word. Science, 21: 29-30. doi:10.1126/science.ns-21.520.29

Holmes, W.H. 1893b, Are there traces of man in the Trenton Gravels. Journal of Geology, 1: 15-37. doi:10.1086/606134

Holmes, W.H. 1897, Stone implements of the Potomac-Chesapeake tidewater province. In: Fifteenth Annual Report of the Bureau of Ethnology for 1893-1894 (J. W. Powell, Ed.). Government Printing Office, Washington, D.C.: p. 13-152.

URL: https://library.si.edu/digital-library/book/annualreportofbu1518931894smit

Knell, E.J. 2014, Terminal Pleistocene-Early Holocene Lithic Technological Organization Around Lake Mojave, California. Journal of Field Archaeology, 39: 213-229. doi:10.1179/0093469014z.00000000087 
Knell, E.J., Walden-Hurtgen, L. \& Kirby, M. 2014, Terminal Pleistocene-Early Holocene spatio-temporal and settlement patterns around Pluvial Lake Mojave, California. Journal of California and Great Basin Anthropology, 34(1): 43-57. doi:10.1179/0093469014z.00000000087

Malinsky-Buller, A., Hovers, E. \& Marder, O. 2011, Making time: 'living floors', 'palimpsests' and site formation processes-a perspective from the open-air Lower Paleolithic site of Revadim Quarry, Israel. Journal of Anthropological Archaeology, 30: 89-101. doi:10.1016/j.jaa.2010.11.002

McFadden, L.D. 2013, Strongly dust-influenced soils and what they tell us about landscape dynamics in vegetated aridlands of the Southwestern United States. In: The Web of Geological Sciences: Advances, Impacts, and Interactions. (M. E. Bickford, Ed.), Geological Society of America Special Paper 500. Geological Society of America, Boulder: p. 501-532. doi:10.1130/2013.2500(15).

McFadden, L.D. 2017, Soils of desert landscapes. In: International Encyclopedia of Geography: People, the Earth, Environment and Technology (Richardson, D. Ed.). Wiley Blackwell, New York: p. 1-19. doi:10.1002/9781118786352.wbieg0880

McFadden, L.D., McDonald, E.V., Wells, S.G., Anderson, K.J. Quade, \& Forman, S.L. 1998, The vesicular layer and carbonate collars of desert soils and pavements: Formation, age and relation to climate change. Geomorphology, 24: 101-145. doi:10.1016/s0169555x(97)00095-0

Meltzer, D.J. 2009, First Peoples in a New World: Colonizing Ice Age America. University of California, Berkeley, 446 p.

Meltzer, D.J. 2015, The Great Paleolithic War: How Science Forged an Understanding of America's Ice Age Past. University of Chicago Press, Chicago, 690 p. doi:9780226293363.001.0001

Meltzer, D.J. \& Dunnell, R.C., (Eds.), 1992, The Archaeology of William Henry Holmes. Smithsonian Institution Press, Washington, 397 p.

Shea, J.J. 2013, Stone Tools in the Palaeolithic and Neolithic Near East: A Guide. Cambridge University Press, Cambridge, 422 p. doi:10.1017/CBO9781139026314

Shott, M.J. 2003, Chaîne opératoire and reduction sequence. Lithic Technology, 28(2): 95105. doi:10.1080/01977261.2003.11721005

Shott, M.J. 2017, Stage and continuum approaches in prehistoric biface production: A North American perspective. PLoS One, 12(3): e0170947. doi:10.1371/journal.pone.0170947

Skarpelis, N., Carter, T., D.A., Contreras, D.A. \& Mihailovic, D.D. 2017, Characterization of the siliceous rocks at Stélida, an early prehistoric lithic quarry (Northwest Naxos, Greece), by petrography and geochemistry: a first step towards chert sourcing. Journal of Archaeological Science: Reports, 12: 819-833. doi:10.1016/j.jasrep.2016.11.015

Volk, E. 1911, The Archaeology of the Delaware Valley. Peabody Museum, Cambridge Massachusetts, $258 \mathrm{p}$.

Wilmsen, E.N. 1965, An outline of early man studies in the United States. American Antiquity, 31: 172-192. doi:10.2307/2693983

Whittaker, J.C. 1994, Flintknapping: Making and Understanding Stone Tools. University of Texas Press, Austin, 341 p. 